Jurnal Riset Agama

Volume 1, Nomor 3 (Desember 2021): 324-342

DOI: $10.15575 /$ jra.v1i3.15596

https://journal.uinsgd.ac.id/index.php/jra

\title{
Tradisi Ijazah pada Prosesi Ngabungbang di Pondok Pesantren Cikalama Sumedang dalam Perspektif Filsafat Kebudayaan
}

\author{
Muhammad Rifqi Hadziqi \\ Jurusan Aqidah dan Filsafat Islam, Fakultas Ushuluddin, \\ UIN Sunan Gunung Djati Bandung \\ rifqihadzieq99@gmail.com
}

\begin{abstract}
Traditional ceremonies and traditions that contain values and norms in society, are a form of culture. In the Cikalama community, there is a Ngabungbang tradition. The purpose of this paper is to answer the problems that are the subject of the research: 1) the Ngabungbang Tradition at Pondok Pesantren Cikalama; 2) The procession of the implementation of the Ngabungbang tradition at the Pondok Pesantren Cikalama; and 3) Sutan Takdir Alisjhabana's cultural philosophy analysis of the Ngabungbang tradition at the Pondok Pesantren Cikalama. This research is a field research, with this research is a qualitative descriptive method, and the theory of cultural philosophy of Sutan Takdir Alisjahbana as a knife of analysis. The findings in this research are firstly, Ngabungbang is a tradition to have a good relationship with God, the Prophet, ancestors, as well as with the supernatural powers that he believes in, and is defined as a pilgrimage to the graves of ancestors who contributed to the spread of Islam. Second, the procession of implementing the Ngabungbang tradition is carried out in several stages, namely, reading sholawat and dhikr, listening to advice from the organizers and finally waiting for the prayer to be awarded. Third, the analysis of the dominant values of STA shows that the style/character/character of the culture in the Ngabungbang tradition is an expressive culture.
\end{abstract}

Keywords: Cultural Philosophy; Pesantren Cikalama; Tradisi Ngabungbang.

\begin{abstract}
Abstrak
Upacara adat dan tradisi yang mengandung nilai dan norma dalam masyarakat, merupakan salah satu wujud kebudayaan. Pada masyarakat Cikalama terdapat tradisi Ngabungbang. Tujuan tulisan ini ialah untuk menjawab permasalahan yang menjadi pokok bahasan penelitian: 1) Tradisi Ngabungbang di Pondok Pesantren Cikalama; 2) Prosesi pelaksanaan tradisi
\end{abstract}


Jurnal Riset Agama, Volume 1, Nomor 3 (Desember 2021): 324-342

Muhammad Rifqi Hadziqi/Tradisi Ijazah pada Prosesi Ngabungbang di Pondok Pesantren Cikalama Sumedang dalam Perspektif Filsafat Kebudayaan

Ngabungbang di Pondok Pesantren Cikalama; dan 3) Analisis filsafat kebudayaan Sutan Takdir Alisjhabana terhadap tradisi Ngabungbang di Pondok Pesantren Cikalama. Penelitian ini merupakan penelitian lapangan, dengan metode deskriptif kualitatif, dan teori filsafat kebudayaan Sutan Takdir Alisjahbana sebagai pisau analisis. Temuan dalam riset ini ialah pertama, Ngabungbang merupakan tradisi untuk berelasi baik dengan Tuhan, Nabi, leluhur, maupun dengan kekuatan ghaib yang diyakininya, dan diartikan berziarah ke makam leluhur yang berjasa dalam penyebaran agama Islam. Kedua, prosesi pelaksanaan tradisi ngabungbang dilakukan beberapa tahap yaitu, membacakan sholawat dan dzikir, mendengarkan wejangan (nasehat) dari pihak penyelenggara dan terakhir menanti turunnya do'a yang akan diijazahkan. Ketiga, analisis nilai-nilai dominan Sutan Takdir Alisjahbana menunjukkan bahwa corak/watak/karakter kebudayaan dalam tradisi Ngabungbang termasuk kebudayaan ekspresif.

Kata kunci: Filsafat kebudayaan; Pesantren Cikalama; Tradisi Ngabungbang.

\section{Pendahuluan}

Masyarakat dan budaya layaknya dua sisi pedang yang saling terkait dan terikat (Alfan, 2013: 54). Menurut Koentjoroningrat, ada tiga wujud kebudayaan, pertama, sebagai ide atau gagasan, nilai, dan norma secara kolektif yang hidup di masyarakat, serta memberi jiwa bagi masyarakat. Kedua, sebagai konsep sistem sosial untuk berinteraksi antar masyarakat. Ketiga, sebagai benda-benda yang merupakan hasil karya manusia (Surjawa, 1999: 10-12).

Upacara adat dan tradisi yang mengandung nilai dan norma dalam masyarakat, merupakan salah satu wujud kebudayaan. Di mana nilai dan norma tersebut dilaksanakan dan dipatuhi oleh masyarakat. Di Indonesia banyak sekali wujud kebudayaan, dalam bentuk tradisi atau semacam ritual-ritual yang bernuansa religi atau agama. Masyarakat Indonesia dari dulu hingga hari ini masih banyak yang percaya pada hal-hal atau bendabenda yang dianggap memiliki kekuatan gaib, seperti batu, pohon, keris, pedang, dan lainnya. Sehingga dari kepercayaan tersebut manusia mesti menjalin hubungan yang baik dengan alam, yaitu dengan mengadakan upacara simbolik, membacakan do'a, serta memberikan sesaji (Jamil, 2000: $54)$.

Islam adalah agama yang lentur dan dapat menyesuaikan ajaranya, dengan kondisi suatu masyarakat di daerah tertentu. Dengan 
Jurnal Riset Agama, Volume 1, Nomor 3 (Desember 2021): 324-342

Muhammad Rifqi Hadziqi/Tradisi Ijazah pada Prosesi Ngabungbang di Pondok Pesantren Cikalama Sumedang dalam Perspektif Filsafat Kebudayaan

kelenturannya tersebut Islam dapat diterima dengan mudah oleh masyarakat Indonesia (Soehadha, 2013: 15-16). Khususnya di pulau Jawa, Islam dibawa oleh para wali dengan cara dan pendekatan yang halus, merupakan contoh pendekatan Islam melalui memasukan nilai-nilai ajaran Islam dalam unsur-unsur budaya lokal. Hal tersebut dilakukan agar masyarakat dapat dengan mudah menerima ajaran Islam serta dapat mengaplikasikannya dalam kehidupan. Masyarakat Jawa Barat misalnya, dikenal sebagai masyarakat yang religius dan patuh dalam menjalakan ajaran Islam. Hal tersebut dapat terlihat dengan banyaknya tempat ibadah (Langgar), dan pondok pesantren di setiap pemukiman warga. Selain itu masyarakat di Jawa Barat, masih menjunjung tinggi nila-nilai kebersamaan, kerukunan, maupun kekerabatan. Jika melihat akan hal tersebut, maka tidak heran jika masih banyak kebudayaan-kebudayaan lokal yang mengandung nilai-nilai Islam dan masih terus dilestarikan, salah satu contohnya adalah tradisi Ngabungbang.

Tradisi Ngabungbang adalah suatu tradisi keagamaan yang muncul dari dorongan manusia untuk melakukan berbagai hal yang memiliki tujuan untuk berelasi dengan dunia gaib (kelakuan keagamaan). Semua fenomena alam yang mereka saksikan, seperti gunung, batu, sungai, laut, dan angin yang sesekali mengganggu kehidupan manusia. Menurutnya, semua menifestasi alam tersebut memiliki roh, misalnya roh nenek moyang yang selalu hadir mengamati mereka.

Ngabungbang merupakan tradisi yang ada di beberapa wilayah di Jawa Barat. Yang dimaksud Ngabungbang ialah "cicing di luar wawangunan bari teu sare sapeuting jeput, utamana dina tempat anu aya karamatan nu dilaksanakeun dina malam caang bulan ka 14." Artinya diam di luar bangunan dengan bergadang semalaman terutama di tempat yang dianggap keramat dan dilaksanakan setiap malam purnama ke-14 (Nalurita, 2013: 2).

Tradisi ini mulai tergerus zaman, sehingga tidak banyak orang yang mengetahuinya. Terlebih hanya sebagian daerah tertentu saja di Jawa Barat yang mengenal tradisi ini, dan setiap daerah mempunyai corak masingmasing terkait ritual Ngabungbang itu sendiri, yaitu dilakukan dengan cara yang berbeda-beda walaupun pada pemaknaannya ada kemiripan dalam mendefinisikan tradisi tersebut.

Adapun tradisi Ngabungbang yang dimaksud dalam tulisan ini ialah yang dilakukan di pondok pesantren Cikalama Sindangpakuon Sumedang. Tradisi Ngabungbang di pondok pesantren Cikalama hanya dilaksanakan sekali dalam setahun. Secara historis tradisi Ngabungbang berasal dari Karahayuan Limbangan yang diijazahkan pada bulan Maulud, yang kini dikenal denga istilah Ngabungbang. Melaksanakan Ngabungbang diartikan juga sebagai memperingati hari lahirnya Nabi Muhammad SAW. Yang dimaksud Ijazah Karahayuan (keselamatan) dalam prosesi ini ialah merupakan kalimat turun-temurun yang dianggap sakral sehingga tidak 
Jurnal Riset Agama, Volume 1, Nomor 3 (Desember 2021): 324-342

Muhammad Rifqi Hadziqi/Tradisi Ijazah pada Prosesi Ngabungbang di Pondok Pesantren Cikalama Sumedang dalam Perspektif Filsafat Kebudayaan

bisa didokumentasikan baik dalam bentuk tulisan maupun media. Bacaan atau amalan yang dibacakannya yaitu seperti, sholawat, wirid, bahasa Sunda buhun, dan bahasa wali (Arab) (Fauzi, 2021: 7:16).

Dalam konteks masyarakat muslim pedesaan, ritual keagamaan merupakan entitas yang takterpisahkan dengan identitasnya. Pupuhu masyarakat baik ajengan, wali, kiai selaku memegang otoritas keagamaan senantiasa memelihara budaya sebagai media penyaluran doktrin Islam (Albustomi, 2019).

Tradisi Ngabungbang dilaksanakan pada malam bulan purnama, atau pada tanggal 14 Maulud / 14 Rabi'ul Awal. Warga yang mengikuti tradisi ini berkumpul di halaman luar ponpes Cikalama pada tengah malam tepatnya pukul 24:00 untuk membaca suatu amalan atau wirid atau ijazah. Kalimatnya berupa hafalan dengan menggunakan bahasa Sunda kuno dan mempunyai syarat-syarat tertentu, yaitu tidak boleh ditulis maupun direkam, harus dibaca di luar ruangan, tidak boleh dibacakan oleh wanita haid, dipimpin pertama kali oleh perempuan, harus mempunyai wudhu, dan harus diikuti sebanyak tujuh kali secara berturut-turut. Seseorang yang mampu menghafal ijazah tersebut dipercaya akan mendapat suatu kebaikan dan terlindung dari hal-hal buruk, misalnya dibaca ketika menyembuhkan orang sakit dan dalam keadaan kesusahan (Fauzi, 2021: $7: 16)$.

Untuk memperkaya dan memperjelas posisi tulisan ini, peneliti sajikan beberapa penelitian sebelumnya untuk membantu peneliti dalam menentukan langkah-langkah sistematis dari teori yang akan digunakan, sehingga penulis dapat dengan tepat menggunakan analisis teori pada objek yang akan diteliti. Berikut beberapa riset sebelumnya yang patut untuk diulas.

Darajat (2020) menulis "Pendidikan Karakter dalam Tradisi Ngabungbang Masyarakat Adat Kasepuhan Ciptagelar." Temuan penelitian ini menunjukkan bahwa tradisi Ngabungbang mampu mewujudkan nilainilai pendidikan karakter seperti religius, toleransi, kejujuran, kreatif, komunikatif, tanggung jawab, dan cinta tanah air. Selain itu dalam tradisi tersebut juga terdapat nilai-nilai pendidikan karakter Sunda "tri-SILAS" atau tiga prinsip yakni, silih asih, silih asah, dan silih asuh (Darajat, 2020: 137-142).

Octaviani (2020) menulis "Upacara Ngabungbang Pada Masyarakat Cikalama Sindangpakuon Cimanggung Sumedang Tahun 2020.“ Temuan dalam penelitian ini menunjukkan bahwa tradisi upacara Ngabungbang, sebuah do'a Karahayuan, yang diartikan sebagai simbol sosial bagi mereka yang bergabung dalam kegiatan tersebut. Tujuan Ngabungbang adalah berziarah ke makam leluhur yang berjasa dalam penyebaran ajaran Islam di Sindangpakuon dan sekitarnya, membacakan puji-pujian, 
Jurnal Riset Agama, Volume 1, Nomor 3 (Desember 2021): 324-342

Muhammad Rifqi Hadziqi/Tradisi Ijazah pada Prosesi Ngabungbang di Pondok

Pesantren Cikalama Sumedang dalam Perspektif Filsafat Kebudayaan

mendengarkan wejangan (nasehat) dari pihak penyelenggara dan menanti turunnya do'a yang akan diijazahkan (Octaviani, 2020).

Gunaepi (2020) membahas "Analisis Tradisi Ngabungbang di Hulu Citarum (Studi Fenomenologi Tradisi Ngabungbang sebagai Wujud Kearifan Lokal Masyarakat Kertasari di Hulu Citarum)." Temuan penelitian ini menjelaskan bahwa tradisi ngabungbang merupakan proses menyucikan diri, baik fisik maupun batin. Bagi masyarakat Hulu Citarum tradisi ini sudah menjadi warisan para leluhur yang senantiasa harus dilestarikan (Gunaepi, 2020).

Beberapa studi di atas, mengulas tradisi Ngabungbang dengan berbagai perspektifnya. Terlepas ada persamaan dalam hal metodologi dan lainnya, namun tulisan ini akan membahas tradisi tersebut dalam tinjauan filsafat kebudayaan Sutan Takdir Alisjhabana. Kebudayaan menurut Alisjhabana adalah ciptaan khas manusia yang lahir dari akal budi, insting, pikiran, perasaan, kemauan, dan fantasi manusia. Kebudayaan diciptakan manusia sebagai sebab akibat dari transendensi (pengatasan) manusia atas alam. Kebudayaan suatu bangsa memiliki watak dan karakter yang khas, yang terletak pada nilai-nilai (values) paling dominan yang dijunjung tinggi oleh bangsa tersebut. Nilai-nilai dominan tersebut ialah:

Pertama, nilai seni dan agama. Nilai seni (estetik) ialah nilai dominan yang menekankan pada keindahan, yang mengungkap diri dalam dunia sekitar. Sementara nilai religius merupakan nilai dominan yang menekankan pada keterhubungan antara diri dan kekuatan misterius adialamiah yang menakjubkan, tapi sekaligus menegangkan di alam yang juga penuh misteri. Nilai religius adalah nilai yang menekankan pada pentingnya eksistensi Sang Kudus (the holiness).

Kedua, nilai ilmu (sains), teknologi, dan ekonomi. Nilai teoritis dan teknologi merupakan nilai dominan yang menekankan pada pengetahuan obyektif untuk mengidentifikasi hal-hal dan kejadian-kejadian di sekitar tempat hidup manusia. Sedangkan nilai ekonomis yaitu nilai dominan yang mengutamakan pemanfaatan lingkungan dan efisiensi pemanfaatannya untuk melestarikan dan menikmati hidup.

Ketiga, nilai kekuasaan (power) dan solidaritas. Nilai kekuasaan adalah nilai dominan yang menekankan pada ambisi untuk menguasai orang lain dalam kuasa vertikal (hirarki antara atasan-bahawahan). Dan nilai solidaritas adalah nilai dominan yang menekankan keutamaan percitaan, persahabatan, gotong royong (mutual help) dalam kuasa horisontal (sejajar antara kekasih, sahabat, dan warga negara) (Alisjahbana, 1986: 278).

Ketiga nilai-nilai dominan tersebut akan menentukan corak, watak, atau karakter khas suatu kebudayaan. Dengan demikian, dalam batas-batas tertentu teori nilai-nilai dominan Alisjhabana ini akan digunakan untuk menganalisi tradisi Ngabungbang yang ada di Pondok Pesantren Cikalama Sumedang, agar bisa melihat secara utuh, mendalam, dan objektif. 
Jurnal Riset Agama, Volume 1, Nomor 3 (Desember 2021): 324-342

Muhammad Rifqi Hadziqi/Tradisi Ijazah pada Prosesi Ngabungbang di Pondok Pesantren Cikalama Sumedang dalam Perspektif Filsafat Kebudayaan

Tujuan penelitian ini untuk menjawab beberapa permasalahan yang dijadikan pokok pembahasan, yakni meliputi: 1) Tradisi Ngabungbang di Pondok Pesantren Cikalama; 2) Prosesi pelaksanaan tradisi Ngabungbang di Pondok Pesantren Cikalama; dan 3) Analisis filsafat kebudayaan Sutan Takdir Alisjhabana terhadap tradisi Ngabungbang di Pondok Pesantren Cikalama.

Manfaat hasil penelitian ini untuk menambah dan memperluas khazanah keilmuan, terkhusus mengenai tradisi yang bercorak keislaman di Jurusan Aqidah dan Filsafat Islam Fakultas Ushuluddin. Dengan adanya hasil penelitian ini, penulis berharap agar bisa mengajak masyarakat merawat tradisi-warisan leluhur bangsa, khususnya tradisi lokal.

Berangkat dari uraian diatas, penelitian ini berusaha menyusun bangunan penelitian yang berupa; rumusan, pertanyaan dan tujuan penelitian (Darmalaksana W. , 2020). Rumusan masalah dalam penelitian ini sebagaimana yang tertera dalam abstraksi yaitu tradisi ijazah pada prosesi ngabungbang di pondok pesantren Cikalama, prosesi ijazah pada tradisi ngabungbang, dan analisis filsafat kebudayaan Sutan Takdir Alisjahbana terhadap tradisi ijazah pada prosesi ngabungbang di pondok pesantren Cikalama. Penelitian ini bertujuan menjawab rumusan masalah yang sebelumnya telah peneliti paparkan.

\section{Metode Penelitian}

Metode yang digunakan dalam penelitian ini ialah metode deskriptif kualitatif, yaitu metode yang digunakan untuk melakukan penelitian pada suatu kondisi masyarakat, maupun sistem suatu pemikirannya, maupun suatu peristiwa yang terjadi saat ini. Metode ini bertujuan untuk menjelaskandan menggambarkan, suatu fenomena dengan cara yang sitematis, faktual, serta akurat (Sugiyono, 2014: 207).

Sumber data yang digunakan yaitu data primer dan sekunder. Data primer diperoleh langsung dari sumber pertama, yaitu masyarakat, tokoh adat, dan pimpinan Pondok Pesantren Cikalama. Sementara data sekunder adalah data pendukung atau data tambahan yang diperoleh dari sumbersumber yang berkaitan dengan pembahasan penelitian yang akan dilakukan, seperti buku, jurnal, skripsi, artikel, dan karya ilmiah lainnya (Saifuddin, 2016: 60).

Penentuan informan dalam penelitian ini menggunakan teknik purposive sampling (sampling bertujuan). Teknik ini merupakan teknik penentuan informan melalui pertimbangan-pertimbangan tertentu. Pertimbangan tersebut dilakukan seperti menentukan informan atau seseorang yang dianggap paling mengetahui tentang apa yang akan dibutuhkan dalam penelitian, atau seseorang tersebut merupakan penguasa atau seseorang yang memiliki posisi tertentu, sehingga akan 
Jurnal Riset Agama, Volume 1, Nomor 3 (Desember 2021): 324-342

Muhammad Rifqi Hadziqi/Tradisi Ijazah pada Prosesi Ngabungbang di Pondok

Pesantren Cikalama Sumedang dalam Perspektif Filsafat Kebudayaan

memudahkan peneliti untuk menjelajahi, atau memperoleh data dari objek ata situasi yang akan diteliti (Sugiyono, 2014: 208).

Adapun waktu dan tempat dalam penelitian ini, yaitu di Pondok Pesantren Cikalama Sumedang dan dilakukan dari bulan Juni sampai Oktober 2021. Penelitian ini dilakukan pada 4 orang informan yaitu: Rd. Fegi Muhammad Husen Mahali Fauzi (Pimpinan Pondok Pesantren Cikalama Sumedang), Aden Babam (sekretaris Pondok Pesantren Cikalama), Habib Djati Cakra Nugraha (Sejarawan dan budayawan Desa Limbangan), dan Febrianti (masyarakat Pondok Pesantren Cikalama).

\section{Hasil dan Pembahasan}

\section{Tradisi Ngabungbang di Pondok Pesantren Cikalama}

Penelaahan tradisi Ngabungbang seyogianya dilihat secara kesejarahan yang telah mengakar lama di masyarakat Cikalama. Adapun tradisi yang telah mengakar di masyarakat diarakhan pada fakta-fakta kesejarahan yang menunjukan adanya acuan (referensi) yang ditunjukan para pendahulu masyarakat di suatu tempat yang dilakukan secara turuntemurun dari satu generasi ke generasi selanjutnya (Madriani, 2021).

Secara historis tradisi Ngabungbang ada sejak abad $18 \mathrm{M}$ dan di abad 19 M mulai dikenal masyarakat, khususnya di kalangan ulama dan santri (Nugraha, 2021: 7:21). Tradisi Ngabungbang adalah suatu teradisi keagamaan yang muncul dari dorongan manusia untuk melakukan berbagai hal yang memiliki tujuan untuk berelasi dengan dunia gaib (kelakuan keagamaan). Awalnya dulu ada seorang wali yang dijuluki Eyang Salinggih Ibrahim, dan memiliki nama asli Raden Pringga Kusumah. Beliau adalah orang yang menyiarkan Islam di daerah Limbangan. Eyang Salinggih awalnya bertapa di Gunung Galunggung selama 7 tahun, dengan tujuan untuk beruzlah (Babam, 2021: 7:16).

Adapun tujuan uzlah tersebut ialah: 1) Untuk mengasingkan diri dari keramaian, agar dapat menjalankan ibadah secara khidmat dan tenang; dan 2) Untuk pengharapan agar ia dan kelurga memperolah keselamatan baik di dunia maupun akhirat.

Seraya perjalanan pertapaannya, Eyang Salinggih didatangi oleh seorang perempuan tepat jam 12 malam dan memberikan sebuah do'a, yang mana do'a tersebut dikenal sebagai do'a "Karahayuan Limbangan" dan sampai hari ini selalu dibacakan dalam tradisi Ngabungbang.

Dalam pengertiannya Ngabungbang berasal dari bahasa sanskerta yakni, Ngabingbing yang memiliki arti membimbing. Sementara, secara asal katanya Ngabungbang berasal dari kata bungbang yang artinya germeulap, terang, dian atau pelita, dalam bahasa Sundanya memiliki arti caang mabrak. Namun, secara umum Ngabungbang dapat diartikan sebagai tradisi berziarah malam hari pada bulan purnama (Babam, 2021: 7:16). 
Jurnal Riset Agama, Volume 1, Nomor 3 (Desember 2021): 324-342

Muhammad Rifqi Hadziqi/Tradisi Ijazah pada Prosesi Ngabungbang di Pondok Pesantren Cikalama Sumedang dalam Perspektif Filsafat Kebudayaan

Pada konteks Ngabungbang di pesantren Cikalama adalah untuk berziarah ke makam-makam para leluhur yang dianggap sebagai cikal bakal penduduk setempat dan berjasa dalam meyiarkan ajaran Islam di daerah tersebut. Selain itu, tujuan Ngabungbang ialah untuk bermunajat pada Allah serta mengingat kematian (dizkrul maut) agar manusia selalu ingat kemana ia akan pulang.

Ngabungbang juga memiliki makna lain, yaitu sebagai penghormatan mereka terhadap jasa-jasa leluhur. Hal tersebut, terbukti dengan adanya makam mama Cikalama atau Syekh Abdul Jalil yang berada di daerah Cikalama Desa Sindangpakuon, yang menjadi salah satu tempat dalam proses upacara Ngabungbang. Oleh penduduk setempat, Ngabungbang selalu dijadikan sebagai sarana untuk memperoleh ilmu dari para leluhur. Melalui tradisi ini, banyak orang yang berdatangan ke desa Sindangpakuon untuk mengikuti prosesi Ijazah dalam upacara Ngabungbang, dengan maksud agar memperoleh ilmu Karahayuan. Hal tersebut, seperti yang disampaikan oleh pimpinan pesantren Cikalama sebagai berikut:

Jadi, melalui tradisi Ngabungbang ini, banyak warga atau masyarakat yang datang berduyun-duyun ingin mengikutinya, dengan harapan mereka bisa memperoleh karamat dari para leluhur. Karamat karahayuan itu berisi do'ado'a dan mantra-mantra yang sebagaiannya terdiri dari kalimatullah seperti Asmaul Husna dan diakhiri kalimat tahlil (Babam, 2021: 7:16).

Untuk mendapatkan ilmu tersebut masyarakat harus mengikuti serangkaian kegiatan dan tindakan yang membutuhkan kekuatan, ketekunan, dan kesabaran. Masyarakat yang ikut upacara ini, dituntut untuk mempunyai keyakinan yang kuat dan ilmu pengetahuan yang mumpuni. Selebihnya akan penulis paparkan di point prosesi pelaksanaan Ngabungbang.

Sebagaimana telah disinggung sebelumnya, bahwa Ngabungbang dalam bahasa Sanskerta memiliki arti ngabingbing. Semua keinginan dan harapan jama'ah diungkapkan dalam prosesi upacara Ngabungbang. Upacara tersebut dilaksanakan setiap tahun pada malam bulan purnama 14 Maulid (Rabi'ul Awal). Menurut masyarakat bulan tersebut penuh dengan rahmat, sebab pada bulan ini Nabi Muhammad SAW dilahirkan. Selain itu, bulan ini juga merupakan waktu yang baik untuk menyerap ilmu, dan bulan purnama yang penuh itu melambangkan ilmu yang akan diperoleh juga penuh. Keyakinan terhadap waktu dan bulan tersebut akan memberikan hasil yang baik, dan di bulan Maulud tersebut banyak orang yang bertapa (Mustafa, 1996: 232).

Sebelum rangkaian prosesi upacara dilaksanakan, para jama'ah dianjurkan untuk berziarah terlebih dahulu ke makam-makam tokoh penyebar ajaran Islam khususnya di Sumedang. Adapun tempat-tempat 
Jurnal Riset Agama, Volume 1, Nomor 3 (Desember 2021): 324-342

Muhammad Rifqi Hadziqi/Tradisi Ijazah pada Prosesi Ngabungbang di Pondok

Pesantren Cikalama Sumedang dalam Perspektif Filsafat Kebudayaan

tersebut di antaranya: 1) Makam Syekh Abdul Jalil di Cikalama desa Sindangpakuon; 2) Makam Girilaya Pasirnanjung Cimanggung; 3) Makam Bangkir di Sindanggalih Cimanggung; 4) Makam Haruman di Limbangan Garut; dan 5) Makam Mama Cibalampu di kecamatan Cibalampu.

Jika kelima makam terebut dikunjungi, maka nuansa prosesi upacara pun akan terasa lebih lengkap. Kendati demikian, karena faktor waktu dan lain hal, hal tersebut tidak menjadi anjuran mutlak bagi masyarakat yang hendak mengikuti tradisi ini. Kebanyakan dari mereka adalah para kiai dan santri, namun ada juga dari kalangan petani, pedagang, pegawai negeri, maupun pelajar. Usia tua dan muda tak mejadi hambatan untuk mengikuti tradisi ini, dengan catatan sudah baligh (Babam, 2021: 7:16).

Dalam rangkaian upacara Ngabungbang, terdapat dua pihak yang berkaitan langsung dengan proses acara, yakni jama'ah dan penyelenggara. Jama'ah ialah orang-orang yang mengikuti upacara Ngabungbang, sementara penyelenggara adalah sesepuh desa atau tokoh adat, dalam hal ini adalah keluarga Kiai Raden Yuyu Yusup, anak-anak dan saudaranya. Kiai Raden Yuyu Yusup adalah tokoh adat sekaligus ulama yang pertama kali mengenalkan tradisi Ngabungbang di wiliyah Sumedang (Babam, 2021: 7:16).

\section{Prosesi Pelaksanaan Tradisi Ngabungbang di Pondok Pesantren Cikalama \\ a) Tahapan Pelaksanaan Tradisi Ngabungbang}

Pelaksanaan tradisi upacara Ngabungbang terpusat di Rt 03 Cikalama Desa Sindangpakuon Kecamatan Cimanggung Kabupaten Sumedang. Terdapat beberapa tahapan dalam pelaksanaan tradisi upacara Ngabungbang, pertama, bimbingan dan dzikir; kedua, wejangan (nasihatnasihat); dan Ketiga, adalah tahapan puncak yaitu pemberian hadiah atau "ijazah". Sebelum mengikuti rangkaian upacara tersebut, para jama'ah dianjurkan untuk berwudhu terlebih dahulu, agar diri mereka dalam keadaan suci dan lebih baik dalam niat ataupun pelaksanaannya (Babam, 2021: 7:16).

Ketika sudah memasuki waktu pelaksanaan acara ini, banyak jama'ah yang berdatangan dari berbagai daerah, mereka harus sudah di tempat sebelum waktu maghrib, bahkan ada dari mereka yang datang lebih awal agar bisa mengikuti acara tersebut. Sebelum upacara dimulai, jama'ah berkumpul untuk mempersiapkan hal-hal apa saja yang harus dilaksanakan dalam prosesi Ngabungbang tersebut. Seperti yang disampaikan oleh Skretariat Pondok Pesantren Cikalama berikut:

Sebelum prosesi upacara Ngabungbang, itu biasanya jama'ah dikumpulkan terlebih dahulu untuk diberikan arahan dan mempersiapkan langkah-langkah apa saja yang harus dilakukan nanti. Arahan itu ya berisi wejangan-wejangan 
Jurnal Riset Agama, Volume 1, Nomor 3 (Desember 2021): 324-342

Muhammad Rifqi Hadziqi/Tradisi Ijazah pada Prosesi Ngabungbang di Pondok Pesantren Cikalama Sumedang dalam Perspektif Filsafat Kebudayaan

seputar tata cara mengikuti upacara ini gimana, dan wejangan tersebut disampaikan langsung oleh pihak keluarga Kiyai Raden Yuyu Yusup sebagai penyelenggara acara (Babam, 2021: 7:16).

Kegiatan ini dimulai setelah waktu isya, acara diawali dengan pembacaan sholawat-sholawat dan dzikir, yang dilakukan berasama-sama oleh pemimpin dan para jama'ah. Kemudian, dilanjutkan dengan penyampaian wejangan-wejangan filosofis tentang nasehat-nasehat yang berkaitan dengan kehidupan dan hal-hal baik sesuai ajaran Islam. Di tahap kedua ini, para jama'ah dilarang melakukan hal-hal lain yang dapat mengganggu dan merusak acara sakral tersebut. Sebaliknya, para jama'ah diwajibkan untuk bisa serius dan khusyu dalam mendengarkan dan membacakan kalimatullah tersebut.

Sebagaimana telah disinggung di atas, bahwa peserta jama'ah Ngabungbang ini tidak dibatasi oleh jenis kelamin, hanya saja dalam usia batas untuk mengikuti upacara ini harus sudah baligh. Baligh dalam artian sudah dapat membedakan mana yang baik dan yang buruk.

Awalnya tradisi Ngabungbang dilakukan oleh 7 orang di Cikalama, namun seiring berjalannya waktu peserta jama'ahnya semakin bertambah, terakhir prosesi upacara pada 30 Otober 2020 jama' ahnya kurang lebih ada 4000 orang. Hal ini dituturkan oleh pimpinan Pondok Pesantren Cikalama berikut:

Awalnya yang menjalankan tradisi Ngabungbang di Cikalama ini hanya 7 orang, tapi dari tahun ke tahun alhamdulillah jama'ahnya terus bertambah. Terakhir di tahun 2020 lalu, itu ada sekitar 4000 jama'ah yang mengikuti upacara ini. Dan jama'ah itu tidak hanya dari warga sini saja, dari luar daerah juga sangat banyak. Oleh karena itu seketika tempat ini manjadi sesak, sampe tidak ada tempat yang kosong (Fauzi, 2021: 7:16).

Selanjutnya tahapan terakhir atau acara inti, dilaksanakan pada pukul 24:00, pada jam ini akan diberikan sebuah do'a atau disebut "Ijazah" yang diberikan oleh Ibu Hajah Ndeh Sa'adah. Beliau merupakan kakak dari ketua Pondok Pesantren Cikalama yakni Kiai Raden Yuyu Yusup. Do'a tersebut bukan sembarang do'a, do'a ini merupakan mantra-mantra yang terdiri dari rangkaian kata-kata bahasa kuno yang tak mudah dimengerti begitu saja oleh orang awam. Dalam pemberian ijazah tersebut terdapat catatan khusus dan sejumlah syarat yang harus dipatuhi dan dipenuhi oleh para jama' ah. Hal tersebut dilakukan untuk menjaga dan mempertahankan kesakralan serta faedah dari tradisi upacara Ngabungbang. Berikut beberapa syarat yang harus dipenuhi dan dipatuhi: 1) Tidak boleh ditulis; 2) Tidak 
Jurnal Riset Agama, Volume 1, Nomor 3 (Desember 2021): 324-342

Muhammad Rifqi Hadziqi/Tradisi Ijazah pada Prosesi Ngabungbang di Pondok Pesantren Cikalama Sumedang dalam Perspektif Filsafat Kebudayaan

boleh direkam; dan 3) Hanya boleh dibacakan di lapangan (bukan di ruangan) dengan secara khidmat (Fauzi, 2021: 7:16).

Selain itu, do'a ini hanya berlaku sampai batas jam 4 sore keesokan harinya. Dalam hal ini, peneliti menemukan kesulitan untuk memperoleh data otentik terkait ijazah (do'a/mantra) yang dibacakan dalam prosesi upacara Ngabungbang, karena alasan tersebut. Terlebih lagi sejauh informasi yang peneliti temukan, do'a atau mantra ini hanya boleh dibacakan (diijazahkan) pada malam tersebut, yakni malam 14 Maulud tepat pukul 24:00.

Setelah rangkaian acara dilakukan, acara kemudian diakhiri dengan jamuan yang telah disediakan oleh penyelenggara acara. Adapun dana yang digunakan untuk jamuan itu, diperoleh dari sumbangan-sumbangan warga Cikalama dan para jama'ah. Sumbangan tersebut tidak hanya berupa uang saja, namun ada juga yang berupa makanan, dan lain-lain Setelah acara jamuan selesai, mereka pun pulang ke rumah masing-masing.

Terkait dengan keampuhan dari do'a dan mantra-mantra tersebut, bagi orang-orang yang meyakini dan mengamalkannya dampaknya sangat terasa begitu nyata. Seperti yang disampaikan oleh Sekretaris Pondok Pesantren Cikalama berikut:

Mantra dan do'a dari ijazah ini manfaatnya sangat nyata sekali, banyak para jama'ah yang telah mengalaminya. Misalnya di tahun 1990 itu pernah ada kecelakaan mobil Bus di daerah Nagreg, dan itu semua penumpangnya hampir meninggal, tapi ada beberapa orang yang selamat seperti Raden Hasan beliau itu dulu lurah di desa Sindanggalih, dan termasuk saya juga penumpang Bus itu yang selamat tanpa luka sedikit pun. Kemudian, sesepuh pondok pesantren yaitu Kiai Raden Yuyu Yusup juga pernah mengalami kecelakaan mobil mini Bus di Garut, tapi alhamdulillah beliau selamat dan sampai hari ini masih sehat wal'afiat. Menurut beliau, keselamatan tersebut adalah wasilah dan berkah dari mantra dan do'a yang telah diijazahkan. Dan masih banyak lagi testimoni-testimoni dari para jama'ah lainnya. Namun, do'a ini tidak boleh dijadikan sebagai kesombongan, sebab bisa menghilangkan wasilah dan keberkahannya. Intinya do'a atau suatu amalan ini bertujuan untuk memohon perlindungan dari Allah (Babam, 2021: 7:16).

Dalam penguasaan ilmu tersebut, setiap jama'ah harus sabar, tekun, dan memiliki keyakinan yang kuat, sebab untuk penguasaan ilmu yang utuh jama'ah harus datang dan mengikuti upacara Ngabungbang ini selama 7 (tujuh) kali berturut-turut. Jika ada satu tahun saja yang terlewat, maka jama'ah harus mengulanginya lagi dari awal. Dan bagi jama'ah yang telah berhasil mengikuti selama 7 (tujuh) kali berturut-turut, tidak ada kewajiban lagi baginya untuk mengikuti upacara di tahun berikutnya, hal tersebut tergantung pada jama'ah itu sendiri. 
Jurnal Riset Agama, Volume 1, Nomor 3 (Desember 2021): 324-342

Muhammad Rifqi Hadziqi/Tradisi Ijazah pada Prosesi Ngabungbang di Pondok Pesantren Cikalama Sumedang dalam Perspektif Filsafat Kebudayaan

Dari ulasan di atas, dapat peneliti simpulkan bahwa tujuan dan motif dari tradisi upacara Ngabungbang ini ialah selain untuk menghormati para leluhur dengan cara berziarah kemakam-makamnya, juga untuk menjalin silaturahmi dengan para alumni santri pondok pesantren Cikalama, ataupun para murid atau siswa yang mengabdi di pondok pesantren tersebut, dan masyarakat. Selain itu, juga untuk menambah amalan-amalan atau do'a untuk selalu mengingat pada Allah, Rasullullah SAW, para sahabat, dan juga ulama-ulama. Dan tentunya yang sangat diharapkan adalah memperoleh keberkahan dari amalan-amalan do'a atau mantra yang telah diijazahkan.

\section{a) Mantra Ijazah dan Do'a pada Upacara Ngabungbang}

Sebagaimana yang telah dipaparkan sebelumnya, tujuan para jama'ah yang mengikuti tradisi Ngabungbang ini adalah untuk memperoleh ilmu Karahayuan Limbangan. Yang mana dalam perwujudannya berupa rangkaian kalimat do'a dan mantra-mantra yang menarik untuk dicermati. Do'a yang diajarkan dihafalkan dan dipahami pada pukul 24:00 atau yang disebut dengan Ijazah, merupakan percampuran antara ajaran leluhur dalam bahasa Sunda buhun dan ajaran Islam dalam bahasa Arab. Adapun yang dimaksud ajaran leluhur ialah ajaran leluhur di tanah Sunda khususnya di Sumedang, ajaran tersebut mencakup hampir semua kebutuhan hidup agar mendapatkan kesejahteraan, misalnya dalam berdagang, pertanian, menolak balak, penyembuhan penyakit, dan lain sebagainya.

Isi do'a yang dibaca dalam tradisi upacara Ngabungbang antara lain: 1) Hadiahan; 2) Keselamatan; 3) Do'a mustajab pada Allah SWT; dan 4) Do'a (mantra) yang tak boleh diungkapkan sedikitpun kecuali dalam prosesi tersebut (Fauzi, 2021: 7:16).

Kepercayaan terhadap mantra-mantra (do'a) yang terdiri dari rangkaian bahasa leluhur (sunda buhun) dan diakhiri dengan rangkaian bahasa Arab. Hal tersebut menunjukkan adanya perpaduan unsur-unsur Islam dan tradisi peninggalan para leluhur Sunda. Adapun terkait kebenaran dan keampuhan mantra dan do'a-do'a tersebut, kembali pada keyakinan masing-masing. Menurut Frazer dalam Koentjaraningrat, segala tindakan atau kegiatan yang disandarkan pada kekuatan alam, termasuk dalam sesuatu yang disebut magis (Koentjaraningrat, 1990: 232).

Keyakinan para jama'ah pada umumnya sangat mengharapkan keampuhan mantra yang diijazahkan tersebut, untuk melindungi diri dan kehidupannya. Mereka yakin do'a Karahayuan Limbangan ini dibuat oleh para leluhur sesuai dengan keyakinan dan kekeramatannya. Pengertian kramat sendiri jika ditinjau dari artinya ialah mulia atau luhur budinya. Hal 
Jurnal Riset Agama, Volume 1, Nomor 3 (Desember 2021): 324-342

Muhammad Rifqi Hadziqi/Tradisi Ijazah pada Prosesi Ngabungbang di Pondok

Pesantren Cikalama Sumedang dalam Perspektif Filsafat Kebudayaan

tersebut menunjukkan bahwa keyakinan pada do'a masih mempunyai kekuatan.

Menurut hemat peneliti, terkait do'a ini dapat dipahami sebab situasi masyarakat yang bersifat religius dan bercorak magis. Jadi, do'a ini memiliki kedudukan dan sakralitas yang tinggi bagi mereka yang benarbenar meyakininya. Hal tersebut dapat dipahami sebab dalam masyarakat yang religius, kesaktian menjadi tolak ukur kepemimpinan seseorang. Terbukti dari tokoh Syekh Abdul Jalil hinggan anak cucunya sangat terkenal dan disegani di desa ini. Jika ditelaah lagi, kesaktian tersebut merupakan peninggalan dari masa pra Hindu, yakni kepercayaan dinamisme yang mengajarkan adanya kekuatan dari benda-benda yang diciptakan oleh orang yang mempunyai kekeramatan. Keyakinan dan kepercayaan tersebut, sampai saat ini masih dipelihara dan banyak ditemukan di berbabgai masyarakat muslim di Indonesia. Namun, bertolak dari kepercayaan dinamisme tersebut dalam masyarakat muslim di pesantren Cikalama do'a atau mantra ini tidak boleh dijadikan sesuatu hal atau benda yang harus disembah dan dipuja-puja secara berlebihan, hal ini terbukti dengan adanya peraturan atau pantangan tidak boleh ditulis ataupun direkam sebagaimana yang telah diulas di atas.

Jika ditelaah lagi lebih dalam, dapat dikatakan juga bahwa sebenarnya keberadaan do'a atau mantra ini sebenarnya merupakan produk Islam. Sebab semua ini hanya persoalan bahasa, Islam tidak melarang berdo'a umatnya berdo'a dengan bahasa apa saja dalam hal ini termasuk bahasa daerah (Sunda).

\section{Analisis Filsafat Kebudayaan Sutan Takdir Alisjhabana terhadap Tradisi Ngabungbang di Pondok Pesantren Cikalama}

Sutan Takdir Alisjahbana atau sering dikenal dengan inisial STA, ia lahir pada tanggal 11 Februari 1908, di Natal, Mandailing Sumatra Utara. Beliau meninggal di Jakarta pada 17 Juli 1994 dalam usia 86 tahun. STA merupakan filsuf kebudayaan, sastrawan, dan ahli tata bahasa Indonesia. Ia juga merupakan salah satu pendiri Universitas Nasional (UNAS) Jakarta (Abidin, 2021: 3).

Sebagaimana yang telah disinggung di atas, kebudayaan menurut Alisjhabana adalah ciptaan khas manusia yang lahir dari akal budi, insting, pikiran, perasaan, kemauan, dan fantasi manusia. Kebudayaan diciptakan manusia sebagai sebab akibat dari transendensi (pengatasan) manusia atas alam. Kebudayaan suatu bangsa memiliki watak dan karakter yang khas, yang terletak pada nilai-nilai (values) paling dominan yang dijunjung tinggi oleh bangsa tersebut. Kaitannya dalam hal ini, nilai-nilai dominan dalam tradisi upacara Ngabungbang ialah sebagai berikut:

\section{a) Nilai Seni dan Agama}


Jurnal Riset Agama, Volume 1, Nomor 3 (Desember 2021): 324-342

Muhammad Rifqi Hadziqi/Tradisi Ijazah pada Prosesi Ngabungbang di Pondok Pesantren Cikalama Sumedang dalam Perspektif Filsafat Kebudayaan

Seperti yang telah disinggung di awal, bahwa nilai seni (estetik) merupakan nilai yang menekankan pada keindahan, yang mengungkap diri dalam dunia sekitar. Dalam konteks tradisi Ngabungbang yang menunjukkan nilai keindahan tentu tidak merujuk pada suatu benda ataupun hasil karya, melainkan lebih pada keindahan suasana kebersamaan dalam prosesi upacara Ngabungbang. Dan nilai-nilai kebersamaan tersebut lebih dominan pada nilai sosial, dan selebihnya akan peneliti ulas di point nilai solidaritas.

Kemudian nilai religius ialah nilai yang menekankan pada keterhubungan antara diri dan kekuatan misterius adi-alamiah yang menakjubkan, tapi sekaligus menegangkan di alam yang juga penuh misteri. Nilai religius adalah nilai yang menekankan pada pentingnya eksistensi Sang Kudus (the holiness) (Alisjahbana, 1986: 278).

Sebagaimana telah disebutkan sebelumnya, bahwa di Cikalama terdapat tokoh agama yakni Syekh Abdul Jalil yang sangat dihormati dan dijaga eksistensinya. Hal tersebut terlihat pada tiap tanggal 14 Maulud masyarakat selalu berdatangan berduyun-duyun untuk berziarah pada makam beliau. Selain untuk memperingati hari lahir Nabi Muhammad SAW, masyarakat juga sangat menantikan turunnya do'a atau mantra dari Ijazah dan mengharapkan berkahnya dari do'a atau mantra tersebut. Hal ini menunjukkan bahwa adanya keterhubungan antara masyarakat yang menjalankan tradisi ini dengan Nabi Muhammad SAW juga dengan para leluhurnya melalui kekuatan do'a atau mantra (magis) yang mereka yakini.

Dalam hal ini, pandangan Islam terhadap tradisi ini, tidak melarangnya dan sangat mendukung, sebab selain masyarakat yang menjalankannya mengerti dan paham akan agama juga tidak ada penyelewengan dalam hal akidah. Justeru nilai-nilai agama yang terkandung di dalam tradisi tersebut sangat bermanfaat dan memberikan energi positif bagi setiap jama'ah yang mengikutinya. Hal yang menguatkan lainnya adalah terlihat dari do'a-do'a yang dibacakan, seperti hadiahan, keselamatan, dan do'a mustajab pada Allah SWT (Fauzi, 2021: 7:16). Bagi mereka (para peziarah) yang menyakininya secara psikologis mereka merasa memperoleh ketenangan, dan secara spiritual mereka merasa terhubung dengan para leluhur salah satunya yaitu Syekh Abdul Jalil.

\section{b) Nilai Ilmu (Sains), Teknologi, dan Ekonomi}

Nilai teoritis dan teknologi merupakan nilai dominan yang menekankan pada pengetahuan obyektif untuk mengidentifikasi hal-hal dan kejadian-kejadian di sekitar tempat hidup manusia. Pada konteks tradisi Ngabungbang yang dimaksud ilmu di sini tentu bukan ilmu pengetahuan dalam bidang sains atau teknologi, akan tetapi ilmu 
Jurnal Riset Agama, Volume 1, Nomor 3 (Desember 2021): 324-342

Muhammad Rifqi Hadziqi/Tradisi Ijazah pada Prosesi Ngabungbang di Pondok

Pesantren Cikalama Sumedang dalam Perspektif Filsafat Kebudayaan

pengetahuan tentang agama dan budaya. Hal tersebut terlihat dari keterangan dari slah satu jama'ah berikut:

Nilai yang terkandung dari Ngabungbang ini sangat positif, selain untuk melestarikan budaya warisan nenek moyang, juga sebagai sarana untuk menuntut ilmu agama, apalagi faedah dari ilmu ini (Karahayuan Limbangan) diyakini dapat melindungi diri kita dari segala bahaya (Febrianti, 2021: 7:17).

Sementara nilai ekonomis ialah nilai dominan yang mengutamakan pemanfaatan lingkungan dan efisiensi pemanfaatannya untuk melestarikan dan menikmati hidup. Dalam hal ini, seperti yang telah diulas sebelumnya, bahwa tradisi upacara Ngabungbang merupakan salah satu acara yang setiap tahunnya selalu dipadati orang pengunjung atau jama'ah. Hal ini memberikan peluang usaha dan mendukung perekonomian masyarakat sekitar, seperti memasang kotak amal dan berjualan makanan (bakso, batagor, bakso tahu, mie ayam, gorengan, dan lain-lain) pakaian muslim (baju koko laki-laki, celana komprang, gamis, jilbab, dan lain-lain), ataupun mainan anak-anak dan lain-lainnya. Keuntungan yang diperolah pedagang dalam semalam itu bisa dua kali lipat dari biasanya, dan hasil dari sumbangan kotak amal tersebut dapat digunakan untuk kepentingan mesjid (Babam, 2021: 7:16). Dan hal tersebutlah yang nampaknya telah menjadikan tradisi Ngabungbang semakin diminati olah masyarakat setiap tahunnya, dan jumlah jama'ahnya pun selalu bertambah.

\section{c) Nilai Kekuasaan (Power) dan Solidaritas}

Nilai kekuasaan adalah nilai dominan yang menekankan pada ambisi untuk menguasai orang lain dalam kuasa vertikal (hirarki antara atasanbahawahan). Dalam tradisi Ngabungbang nilai kekuasaan tidak menjadi nilai-nilai dominan, sebab dalam prosesi pelaksanaannya relasi antara pemimpin acara dan jama'ah tidak dibedakan kedudukannya sebagaimana dalam struktur organisasi. Relasi pemimpin dan jama'ah hanya bersifat sementara selama acara tersebut saja, setelahnya akan berelasi seperti biasa.

Selanjutnya, nilai solidaritas adalah nilai dominan yang menekankan keutamaan percintaan, persahabatan, gotong royong (mutual help) dalam kuasa horisontal (sejajar antara kekasih, sahabat, dan warga negara) (Alisjahbana, 1986: 278). Masyarakat Cikalama termasuk masyarakat yang sosialnya sangat baik, terbukti dengan sesamanya, sikap gotong royong yang masih tinggi dan terpelihara, serta masih semarak jika di kampung tersebut diadakan kegiatan yang bersifat sosial. Selain itu proses penyesuaian yang terjadi pada warga ini juga didukung oleh watak warga desa yang mau bekerja sama. Apalagi di antara warga yang ikut Ngabungbang terlihat kebersamaanya baik dari persiapan acara, maupun di 
Jurnal Riset Agama, Volume 1, Nomor 3 (Desember 2021): 324-342

Muhammad Rifqi Hadziqi/Tradisi Ijazah pada Prosesi Ngabungbang di Pondok

Pesantren Cikalama Sumedang dalam Perspektif Filsafat Kebudayaan

akhir acara dengan memberikan sumbangan makanan ataupun uang demi kelancaran dan kekhidmatan acara tersebut.

Hal menguatkan lainnya ialah masyarakat Cikalama merupakan masyarakat yang bersifat purity (taqlid), dalam artian mereka menjalankan syari'at agama hanya terbatas pada apa yang disampaikan oleh kiai atau ulama yang ada di daerahnya. Sehingga, mereka sangat mendukung adanya kegiatan-kegiatan sosial keagamaan yang telah menjadi tradisi dan warisan nenek moyang masyarakat Cikalama Sindangpakuon. Nilai solidaritas yang hidup di masyarakat Cikalama ialah keharmonisan dan menghindari konflik. Hal tersebut diwujudkan melalui sikap saling menghargai dan menghormati baik yang mengikuti tradisi Ngabungbang ataupun tidak.

Berdasarkan analisa di atas, dapat disimpulkan bahwa Ngabungbang di Cikalama merupakan tempat atau ajang pertemuan orang-orang dari daerah, profesi, golongan yang dapat memberikan berbagai kemungkinan antara lain: 1) Terjadi interaksi antar sesama pengunjung dan implikasinya adalah saling tukar menukar informasi mengenai berbagai hal, baik asalusul, pekerjaan atau kesulitan hidup serta keberuntungan hidup dan lain sebagainya yang pernah terjadi; 2) Antar sesama pengunjung memiliki perasaan yang sama, senasib dan setujuan; dan 3) Dengan adanya informasi dari mulut kemulut mengakibatkan kedudukan Ngabungbang di Cikalama semakin kuat. Akan tetapi dengan adanya tujuan Ngabungbang yang mengharapkan sesuatu dari do'a Ngabungbang tersebut, membuat kecenderungan perilaku yang jauh dari hakikat berziarah yang sesungguhnya.

Meski demikian, keberadaan Ngabungbang di Cikalama mampu memberikan perasaan optimis, tenang dan tentram bagi mereka yang mengikuti dan tergabung di dalamnya.

\section{d) Representasi Corak/Watak/Karakter dalam Tradisi Ngabungbang}

Sebagaimana yang telah diulas sebelumnya, bahwa menurut Sutan Takdir Alisjahbana ketiga nilai-nilai dominan tersebut akan menentukan corak/watak/ karakter khas dalam suatu kebudayaan. Watak atau karakter kebudayaan tersebut ialah: 1) Kebudayaan ekspresif, yaitu kebudayaan yang mementingkan ungkapan perasaan dan emosi; 2) Kebudayaan progresif, yaitu kebudayaan yang mementingkan kemajuan; dan 3) Kebudayaan organisasional, yakni kebudayaan yang mengutamakan organisasi politik dan solidaritas sosial (Alisjahbana, 1988: xxv).

Berdasarkan analisis ketiga nilai-nilai dominan di atas, maka tidak berlebihan jika peneliti simpulkan bahwa corak/watak/karakter kebudayaan dari tradisi Ngabungbang termasuk dalam corak/watak/karakter kebudayaan ekspresif. Hal ini tentu ditunjukkan bahwa tradisi upacara Ngabungbang merupakan ungkapan perasaan atau 
Jurnal Riset Agama, Volume 1, Nomor 3 (Desember 2021): 324-342

Muhammad Rifqi Hadziqi/Tradisi Ijazah pada Prosesi Ngabungbang di Pondok

Pesantren Cikalama Sumedang dalam Perspektif Filsafat Kebudayaan

ekspreasi masyarakat untuk berelasi baik dengan Tuhan, Nabi, leluhur, maupun dengan kekuatan ghaib yang diyakininya.

\section{Kesimpulan}

Berdasarkan hasil dan pembahasan di atas, telah dihasilkan beberapa kesimpulan. Pertama, secara historis upacara Ngabungbang telah ada sejak abad ke 18-19 Masehi, dibawa oleh seorang wali yang bernama Eyang Salinggih Ibrahim yang bertapa di Gunung Galunggung selama 7 tahun, di tengah pertapaan pada tanggal 14 Maulud tepatnya pada pukul 24.00, beliau dihampiri seorang perempuan dan mengijazahkan sebuah do'a, yang dikenal dengan do'a Karahayuan. Kebiasaan Ngabungbang ini diartikan sebagai simbol sosial bagi mereka yang bergabung dalam kegiatan tersebut, yang dilakukan di tempat dan waktu tertentu, juga mengikuti tata cara tertentu. Tujuan Ngabungbang adalah berziarah ke makam leluhur yang berjasa dalam penyebaran Agama Islam di Sindangpakuon dan sekitarnya. Kedua, prosesi pelaksanaan tradisi ngabungbang dilakukan beberapa tahap yaitu, membacakan sholawat dan dzikir, mendengarkan wejangan (nasehat) dari pihak penyelenggara dan menanti turunnya do'a yang akan diijazahkan. Ketiga, analisis nilai-nilai dominan STA menunjukkan bahwa corak/watak/karakter kebudayaan dalam tradisi Ngabungbang termasuk kebudayaan ekspresif. Hal tersebut, ditunjukkan bahwa tradisi ini merupakan ungkapan perasaan atau ekspreasi masyarakat untuk berelasi baik dengan Tuhan, Nabi, leluhur, maupun dengan kekuatan ghaib yang diyakininya.

Demikian ulasan peneliti terkait "Tradisi Ijazah dalam Upacara Ngabungbang di Pondok Pesantren Cikalama Sumedang dalam perspektif Filsafat Kebudayaan Sutan Takdir Alisjahbana." Temuan-temuan dalam penelitian ini memiliki kemungkinan untuk salah. Dengan perkataan lain, argumen-argumen penulis tentang tradisi Ngabungbang di Pondok Pesantren Cikalama, perlu untuk dikaji ulang dalam kajian-kajian selanjutnya. Setidaknya tulisan ini dapat menjadi stimulus untuk mengundang penulis selanjutnya untuk melahirkan sebuah karya yang labih baik.

\section{Daftar Pustaka}

Albustomi, A. G. (2019). Pemahaman Teologi Islam Masyarakat Tentang Peran Ulama. Jurnal Aqidah dan Filsafat Islam.

Alfan, M. (2013). Filsafat Kebudayaan. Bandung: Pustaka Setia.

Alisjahbana, S. T. (1986 : 278). Antropologi Baru. Jakarta: PT. Dian Rakyat. Alisjahbana, S. T. (1988 : 722). Socio-cultural Development in Global and

National Perspective and Its Impacts. Majalah Bulanan Ilmu dan

Budaya, Tahun 10, No. 10/Juli 1988: Universitas Nasional.

Alisjahbana, S. T. (1988 : 25). Kebudayaan sebaga Perjuangan: Perkenalan 
Jurnal Riset Agama, Volume 1, Nomor 3 (Desember 2021): 324-342

Muhammad Rifqi Hadziqi/Tradisi Ijazah pada Prosesi Ngabungbang di Pondok Pesantren Cikalama Sumedang dalam Perspektif Filsafat Kebudayaan

dengan Pemikiran S. Takdir Alisjahbana, suntingan Ignas Kleden et.al.,. Jakarta: PT. Dian Rakyat.

Azwar, S. (1999). Metode Penelitian. Jakarta: Pustaka Pelajar.

Basuki, S. (2010 : 93). Metode Penelitian. Jakarta: Penaku.

Darmalaksana, W. (2020). Metode Penelitian Kualitatif Studi Pustaka dan Studi Lapangan. . Pre-Print Digital Library UIN Sunan Gunung Djati Bandung.

Diyanti. (2021, Mei 28). Bagaimana Prosesi Tradisi Ngabungbang? (Rifqi, Pewawancara)

Gunaepi, D. (2020). Analisis Tradisi Ngabungbang di Hulu Citarum (Studi Fenomenologi Tradisi Ngabungbang sebagai Wujud Kearifan Lokal Masyarakat Kertasari di Hulu Citarum). Universitas ARS.

Jamil, A. (2000). Islam dan Kebudayaan Jawa. Yogyakarta: Gama Media.

Madriani, R. (2021). Living Teologi Tradisi Tolak Bala Bepapas pada Masyarakat Desa Parit Setia Kecamatan Jawai Kabupaten Sambas Kalimantan Barat. Jurnal Penelitian Ilmu Ushuluddin .

Masykur, A. R. (2013). Sejarah Filsafat Barat. Yogyakarta: IRCiSoD.

Nalurita, G. (2013 : 2). Fungsi Ronggeng Ibing Dalam Upacara. Neliti, 2.

Octaviani, S. S. (2020). Upacara Ngabungbang Pada Masyarakat Cikalama Sindangpakuon Cimanggung Sumedang Tahun 2020. Bandung: UIN Bandung.

Soehadha, M. (2016). Tauhid Budaya: Strategi Sinergitas Islam dan Budaya Lokal dalam Perspektif Antropologi Islam. Tarjih, 15-16.

Sugiyono. (2014 : 207-208). Metode Penelitian Kuantitatif, Kualitatif, dan $R \mathcal{E}$ $D$. Bandung: Alfabeta.

Sugiyono. (2014). Metode Penlitian Kuantitatif dan Kualitatif. Bandung: Alfabeta.

Sujarwa. (1999). Manusia dan Fenomena Budaya Menuju Perspektif Moralitas Agama. Yogyakarta: Pustaka Pelajar.

Syarbini, A. (2011). Islam dan Kearifan Lokal (Local Wisdom). Annual Conference On Islamic Studies, 170. 
Jurnal Riset Agama, Volume 1, Nomor 3 (Desember 2021): 324-342 Muhammad Rifqi Hadziqi/Tradisi Ijazah pada Prosesi Ngabungbang di Pondok Pesantren Cikalama Sumedang dalam Perspektif Filsafat Kebudayaan 